\title{
Detection of Mycoplasma hyopneumoniae in lungs and nasal swabs of pigs by nested PCR
}

[Deteç̧ão de Mycoplasma hyopneumoniae em pulmões e suabes nasais de suínos por nested PCR]

\author{
F.M.F. Silva ${ }^{1}$, L.A. Castro ${ }^{1}$, A. Silva Júnior ${ }^{1}$, M.P. Moraes $^{2}$, M.A.S. Moreira ${ }^{2}$, M.R. Almeida ${ }^{1}{ }^{*}$ \\ ${ }^{1}$ Instituto de Biotecnologia Aplicada à Agropecuária - UFV \\ Av. P.H. Rolfs, s/n \\ 36570-000 - Viçosa, MG \\ ${ }^{2}$ Departamento de Veterinária - UFV - Viçosa, MG
}

\begin{abstract}
Fifty-four samples were collected from growing and finishing pigs for the molecular diagnosis of enzootic porcine pneumonia. Nineteen lung fragments were obtained from pigs that showed signs of respiratory disease and 35 nasal swabs were obtained from clinically healthy pigs. For the detection of the bacterial genome in the samples, the nested PCR technique was used to amplify a fragment of 706bp. This fragment was subsequently cloned and sequenced. The sequence of obtained nucleotides was compared with six other sequences of Mycoplasma hyopneumoniae and 11 sequences of other bacteria available in the Genbank. To measure the sensitivity of the nested PCR, serial dilutions $\left(10^{-1}\right.$ to $\left.10^{-15}\right)$ of cloned fragments were conducted based on the concentration of 300ng. Ten lung fragments and eight nasal swabs showed positive for M. hyopneumoniae and the limit of detection was estimated to be $0.3 \mathrm{fg}$ DNA cloned. The sequence of nucleotides obtained showed $99.1 \%$ homology with the other sequences of M. hyopneumoniae, demonstrating that the nested PCR used in this study may provide an important diagnostic tool for the detection of this agent.
\end{abstract}

Keywords: swine, enzootic pneumonia, Mycoplasma hyopneumoniae, nested PCR

\section{RESUMO}

Foram coletadas 54 amostras de animais em fase de crescimento e terminação para o diagnóstico molecular da pneumonia enzoótica suína. Dezenove fragmentos de pulmão foram obtidos de suínos que apresentavam sinais de doença respiratória e 35 suabes nasais foram obtidas de suínos clinicamente saudáveis. Para a detecção do genoma bacteriano nas amostras, foi utilizada a técnica de nested PCR que originou um fragmento de 706pb, o qual foi, posteriormente, clonado e sequenciado. A sequência de nucleotideos obtida foi comparada com outras seis sequências de Mycoplasma hyopneumoniae e 11 sequências de outras bactérias disponiveis no Genbank. Para medir a sensibilidade da nested PCR, foram realizadas diluições seriadas $\left(10^{-1}\right.$ a $\left.10^{-15}\right)$ do fragmento clonado, partindo da concentração de 300ng. Dez fragmentos de pulmões e oito suabes nasais apresentaram resultado positivo para $\mathrm{M}$. hyopneumoniae e o limite de detecção foi estimado em 0,3fg de DNA clonado. A sequência de nucleotídeos obtida foi de $99.1 \%$ de homologia com as outras sequências de M. hyopneumoniae, demonstrando que a nested PCR utilizada neste estudo pode ser uma importante ferramenta de diagnóstico para a detecção desse agente.

Palavras-chave: suino, pneumonia enzoótica, Mycoplasma hyopneumoniae, nested PCR

Recebido em 27 de maio de 2008

Aceito em 15 de outubro de 2008

*Autor para correspondência (corresponding author)

E-mail: marcia@ufv.br 


\section{INTRODUCTION}

Mycoplasma hyopneumoniae is a member of Mollicutes class presenting a small double stranded circular DNA genome of $1,140 \mathrm{~kb}$ (Minion et al., 2004). Enzootic porcine pneumonia (EPP), also called mycoplasmal pneumonia, presents $M$. hyopneumoniae as the primary agent (Hege et al., 2002). EPP is a chronic respiratory disease that causes major economic losses to the pig industry (Thacker, 2006). This disease is found in almost all productive areas in Brazil (Sobestiansky et al., 2001). Infection occurs during direct contact with respiratory secretions from carrier animals, and also by airborne transmission (Stark et al., 1998).

Micoplasmal infection causes pneumonia characterized by a sporadic, dry and nonproductive cough, retarded growth rate, and inefficient utilization of feed (Ross, 1999). Secondary infections caused by bacterial pathogens such as Actinobacillus pleuropneumoniae (Yagihashi et al., 1984) and Pasteurella multocida (Amass et al., 1994) can aggravate clinical manifestations in pigs that are primarily infected with $M$. hyopneumoniae. $M$. hyopeumoniae rapidly spreads under favorable environmental conditions in growing and finishing pigs (Ribeiro et al., 2004). The disease is traditionally controlled by antibiotics but the role of management and housing conditions in EPP development have shown to be very effective (Maes et al., 2000).

Several methods for $M$. hyopneumoniae detection have been developed, and an accurate diagnosis of EPP is a prerequisite for combating the disease (Mayor et al., 2008). The isolation of $M$. hyopneumoniae by culture has not been currently performed by diagnostic laboratories mainly due to the fact that this mycoplasma is one of the most fastidious slow growing microorganism (Marois et al., 2007). Serological analysis specificity using polyclonal antibodies is ambiguous, since cross-reactions occur with two other porcine mycoplasmas such as $M$. flocculare and M. hyorhinis (Freeman et al., 1984; Strasser et al., 1992). Techniques derived from molecular biology to detect mycoplasmas are being applied in veterinary medicine, since the polymerase chain reaction test (PCR) has been widespread used in early diagnosis of diseases (Buzinhani et al., 2007). PCR technology is ideally recommended for $M$. hyopneumoniae diagnosis because it is fast, specific, and can be performed on both living and dead animals (Calsamiglia et al., 2000). Several PCR assays have been developed to specific $M$. hyopneumoniae DNA fragments (Verdin et al., 2000; Kurth et al., 2002). At present, the diagnosis of mycoplasmal pneumonia is based on clinical signs and histopathological lesions in many diagnostic laboratories (Whitford et al., 1994). It is important to notice that the presence of $M$. hyopneumoniae is evidenced during the whole disease course while clinical and pathological signs are dependent on the disease stage (Sorensen et al., 1997; Calsamiglia et al., 2000).

The objective of the present study was to evaluate a nested PCR assay and its sensitivity for the detection of $M$. hyopneumoniae from nasal swabs and lung samples as a diagnostic tool of enzootic pneumonia in pigs.

\section{MATERIAL AND METHODS}

A total of 54 samples of nasal swabs and lung fragments from different pigs were used. Nineteen lung fragments were obtained from both growing and finishing pigs that presented signs of respiratory disease. Thirty-five samples of nasal swabs were randomly obtained from both growing and finishing animals aiming to evaluate either the presence or absence of $M$. hyopneumoniae in clinically healthy animals. Such animals were supervised until they were slaughtered and did not show any kind of clinical signs of the studied disease. Samples randomly obtained were suspended in $2 \mathrm{~mL}$ of $0.1 \mathrm{M}$ phosphate buffered saline solution (PBS) and frozen at $-20^{\circ} \mathrm{C}$.

Samples of nasal swab were collected in farms in Rio de Janeiro and at the Universidade Federal de Viçosa. Lung fragments were donated from a Veterinary Microbiology Company.

A phenol-chloroform extraction method was used to extract DNA from lung samples as described by Sambrook et al. (1989). Nasal swab samples were centrifuged at $12,000 \mathrm{~g}$ for $30 \mathrm{~min}$, and then the cell pellets were resuspended in $1 \mathrm{~mL}$ of lysis buffer [Tris- $\mathrm{HCl} 10 \mathrm{mM}(\mathrm{pH} 7.5)$, $\left.\mathrm{MgCl}_{2} 5 \mathrm{mM}, \mathrm{NaCl} 10 \mathrm{mM}\right]$ and the DNA was 
extracted using phenol-chloroform (Sambrook et al., 1989).

PCR reactions were carried out using two pairs of primers based on a M. hyopneumoniae DNA probe sequence (I141-accession number U 02537), previously described by Blanchard et al. (1996a). These primers amplified a part of the multidrug resistance protein gene, which is a member of ATPbinding cassette transporter genes (Higgins, 1992). Amplifications were performed in a final volume of $25 \mathrm{~mL}$. The reaction mixture consisted of $1.0 \mathrm{U}$ of Taq DNA polymerase ${ }^{1}, 200 \mu \mathrm{M}$ of each dNTP, $0.5 \mu \mathrm{M}$ of each primer, $10 \mathrm{X}$ assay buffer [Tris-HCL $20 \mathrm{mM}$ (pH 8.4), $\mathrm{KCl} 50 \mathrm{mM}]$, and $\mathrm{MgCl}_{2} 2 \mathrm{mM}$. The primers used in the PCR were $\mathrm{Hpl}$ (5'TTCAAATTATAACCTCGGTC-3') and Hp3 (5'AGCAAATTTAGTCTCTCTGC-3'), and around 200 ng of purified DNA were used as a template. The amplification of DNA was achieved by 40 cycles of $95^{\circ} \mathrm{C}$ for $1 \mathrm{~min}, 52^{\circ} \mathrm{C}$ for $1 \mathrm{~min}$, and $72^{\circ} \mathrm{C}$ for $2 \mathrm{~min}$. The combination of $\mathrm{Hp} 4$ (5'CGCTTTAGTACCGATATGGG-3') and Hp6 (5'GCCATTCGCTTATATGGTGA-3') was used for the nested PCR. Two microlitres of the PCR product were transferred to the nested PCR reaction. The reaction mixture was amplified for 40 cycles at $95^{\circ} \mathrm{C}$ for $1 \mathrm{~min}, 55^{\circ} \mathrm{C}$ for $1 \mathrm{~min}$, and $72^{\circ} \mathrm{C}$ for $1 \mathrm{~min}$. In each PCR reaction, a negative control consisting of swine genomic DNA free of $M$. hyopneumoniae, as well as a DNA positive control extracted from a pure culture of $M$. hyopneumoniae, were included. PCR products were analyzed with $1 \%$ agarose gel in a TBE buffer $(89 \mathrm{mM}$ Tris- $\mathrm{HCl}$, $89 \mathrm{mM}$ borate, and $2 \mathrm{mM}$ EDTA) stained with ethidium bromide and visualized under UV illumination.

Nested PCR products were purified by $\mathrm{GFX}^{\mathrm{TM}}$ PCR DNA and a gel band purification kit $^{2}$ and cloned into TOPO TA Cloning $\AA^{3}$. Escherichia coli DH5 $\alpha$ competent cells were used for transformation. Recombinant plasmids were extracted as described by Sambrook et al. (1989). Direct nucleotide sequencing of both strands was performed on an ABI Prism 377 Genetic Analyzer ${ }^{4}$ with a commercially available $\mathrm{kit}^{5}$ according to the protocol of the manufacturer using M13 primers from TOPO TA Cloning® kit.

\footnotetext{
${ }^{1}$ Gibco BRL - Gaithersburg, USA.

${ }^{2}$ Amersham Biosciences - Piscataway, USA.

${ }^{3}$ Invitrogen - San Diego, USA.

${ }^{4}$ Applied Biosystems - Foster City, USA.

${ }^{5}$ ABI PRISM BigDye III Terminator Cycle Sequencing

Ready Reaction ${ }^{\circledR}$, Applied Biosystems, Foster City - USA.
}

A nucleotide sequence consensus was generated by the sequencing of three different recombinant clones from the same isolate which was later deposited in the GenBank under the accession number DQ364651. Nucleotide sequences were searched for with homologies in the GenBank by the BLAST program (Altschul et al., 1990) provided by NCBI, USA. Nucleotide sequences retrieved from GenBank (Table 1) were aligned using the Clustal $\mathrm{W}$ version 1.8 multiple sequence alignment program (Thompson et al., 1994).

Table 1. Bacteria sequences used in nucleotide analysis retrieved from GenBank

\begin{tabular}{lll}
\hline $\begin{array}{c}\text { GenBank } \\
\text { accession } \\
\text { No. }\end{array}$ & \multicolumn{1}{c}{ Species } & Location \\
\hline AE017334 & Bacillus anthracis & USA \\
AE017038 & Bacillus anthracis & USA \\
AE017012 & Bacillus cereus & France \\
CP000001 & Bacillus cereus & USA \\
AE017355 & Bacillus thuringiensis & USA \\
AE015940 & Clostridium tetani & USA \\
AE017146 & Helicobacter hepaticus & USA \\
AE000615 & Helicobacter pylori & USA \\
AE017244 & Mycoplasma hyopneumoniae & Brazil \\
AY143369 & Mycoplasma hyopneumoniae & Switzerland \\
AE017332 & Mycoplasma hyopneumoniae & USA \\
NC_006360 & Mycoplasma hyopneumoniae & USA \\
U02537 & Mycoplasma hyopneumoniae & France \\
U19289 & Mycoplasma hyopneumoniae & France \\
BA000017 & Staphylococcus aureus & Japan \\
AE016750 & Staphylococcus epidermidis & China \\
NC_003143 & Yersinia pestis & USA \\
DQ364651 & Mycoplasma hyopneumoniae & Brazil \\
\hline & &
\end{tabular}

\section{RESULTS AND DISCUSSION}

PCR reactions performed with $\mathrm{Hp} 1$ and $\mathrm{Hp} 3$ primers yielded a detectable DNA fragment of $1561 \mathrm{bp}$. A visible band of the expected size was revealed on gel (data not shown). The nested PCR performed with Hp4 and Hp6 primers amplified a 706bp fragment, as shown in Fig. 1. 


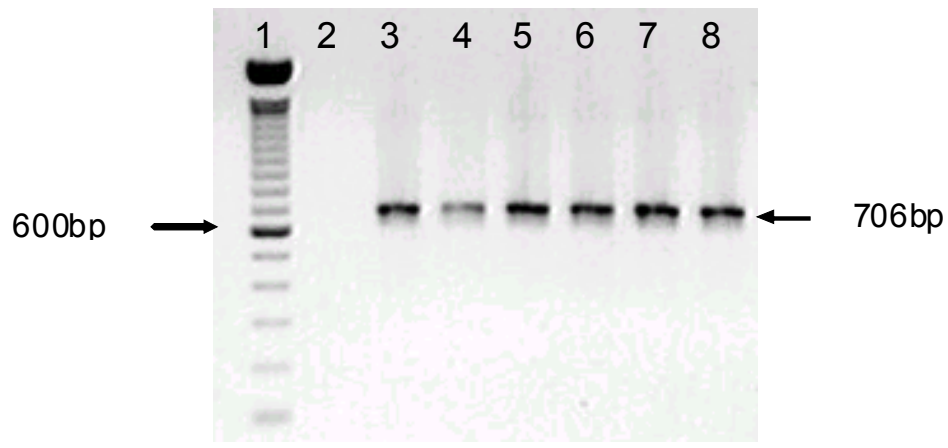

Figure 1. Nested PCR products obtained from the lungs and nasal swabs of pigs. Lane 1: molecular size standard (100bp ladder; Gibco BRL Life Technologies). Lane 2: Negative control: swine genomic DNA free of Mycoplasma hyopneumoniae. Lane 3: positive control: M. hyopneumoniae genomic DNA. Lanes 4 and 5: Nested PCR products from nasal swabs. Lanes 6 to 8: nested PCR products from lungs. The position of the specific fragment is indicated (706bp).

Fifty-four samples consisting of 19 lungs fragments and 35 nasal swabs were analyzed in order to standardize an EPP molecular diagnostic technique. Ten lung fragments and eight nasal swabs presented positive results to $M$. hyopneumoniae.

Positive results obtained with nasal swabs will be of great importance to clinically healthy animals, supervising the quiet dispersal of the infectious agent inside the farm and making in vivo diagnostic of enzootic pneumonia possible. The fact of few nasal swab samples presenting positive results may be due to either absence of clinical signs on tested animals or the absence of the microorganism. Ross (1992) described that diagnosis done by $M$. hyopneumoniae cultivation from nose samples is extremely difficult. That issue could be amended by using the nested PCR technique, once the results found in this work demonstrated the detection of this agent in samples obtained from nasal swabs. Marois et al. (2007) showed that tracheal swabs and tracheobronchiolar washings were the most effective samples to detect $M$. hyopneumoniae compared to nasal or tonsillar swabs, however, tracheal swabs are more difficult to perform under field conditions with older pigs.

According to Calsamiglia et al. (1999), the lung samples stood out as the most appropriate source of $M$. hyopneumoniae detection once this microorganism is known to be present in the nostrils in much smaller numbers than in the lower airways. Verdin et al. (2000) demonstrated that $M$. hyopneumoniae was probably confined to the lower respiratory tract in six-month-old pigs. Otagiri et al. (2005) also found that lung sample detections were higher than in nasal swabs from the same animals.

Once Mycoplasma is apparently present in small quantities in nasal swabs than in lower respiratory tracts, the sensitiveness of a diagnosis method is really important. The sensitivity of nested PCR was also evaluated in this study with 10-fold dilutions of $M$. hyopneumoniae cloned DNA (Fig. 2). A DNA fragment of 706bp was successfully amplified showing as little as $0.3 \mathrm{fg}$ of cloned DNA, a more accurate result than that previously obtained by Verdin et al. (2000), who conducted nested PCR experiments with 10-fold dilutions of $M$. hyopneumoniae genomic DNA and obtained $1 \mathrm{fg}$ of genomic DNA. Calsamiglia et al. (1999) described a nested PCR analysis using specific primers for $M$. hyopneumoniae $16 \mathrm{~S}$ ribosomal DNA. The sensitivity of this nested PCR was approximately $100 \mathrm{fg}$ of genomic DNA.

The specificity of these primers for $M$. hyopneumoniae had been evaluated before by Blanchard et al. (1996a), when DNA from different porcine infectious bacteria (including other Mycoplasma species) had not yielded any amplified product. 
Detection of Mycoplasma hyopneumoniae...

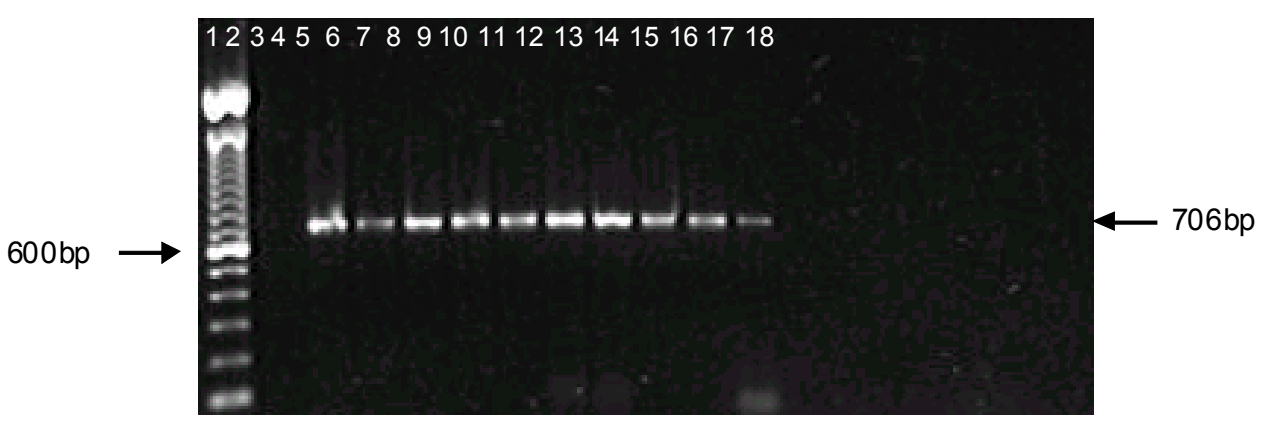

Figure 2. Sensitivity of the nested PCR assay of $M$. hyopneumoniae cloned fragment. Lane 1 contained the molecular size standards (100bp ladder; Gibco BRL Life Technologies). Lanes 2 and 3 contained negative and positive controls, respectively. The amount of DNA added to each reaction shown in lanes 4-18 was 300ng, 30ng, 3ng, 300pg, 30pg, 3pg, 300fg, 30fg, 3fg, 0.3fg, 30ag, 3ag, 0.3ag, 30zg, and 3zg. The position of the specific fragment is indicated (706bp).

The nucleotide sequence of the nested PCR product cloned in TOPO TA Cloning $\AA^{6}$ showed to be a part of multidrug resistance protein gene. The product of this gene is involved in the transport of functions resembling those of the eukaryotic multidrug resistance (MDR) protein family. Such a product might be essential for $M$. hyopneumoniae pathogenicity once it is involved in drug resistance (Blanchard et al., 1996b).

Nucleotide analysis showed that the DQ364651 isolate found in this study had a higher relation to other M. hyopneumoniae sequences from Brazil and the United States, $98.9 \%$ identity, and less homology to French sequences, $97.9 \%$ identity. The obtained sequence was compared to other bacterial multidrug resistance protein genes, being more closely related to Clostridium tetani, Helicobacter pylori, and Helicobacter hepaticus, 43.7\%; 40.3\%; and $43.0 \%$ identity, respectively. The other bacterial sequences retrieved from GenBank exhibited extremely low identity (24-36\%) to the Mycoplasma isolated in this study (Fig. 3). Once this sequence presented low identity to other bacterial species and high identity between $M$. hyopneumoniae sequences this nested PCR assay represents an interesting tool for molecular diagnosis of $M$. hypneumoniae.

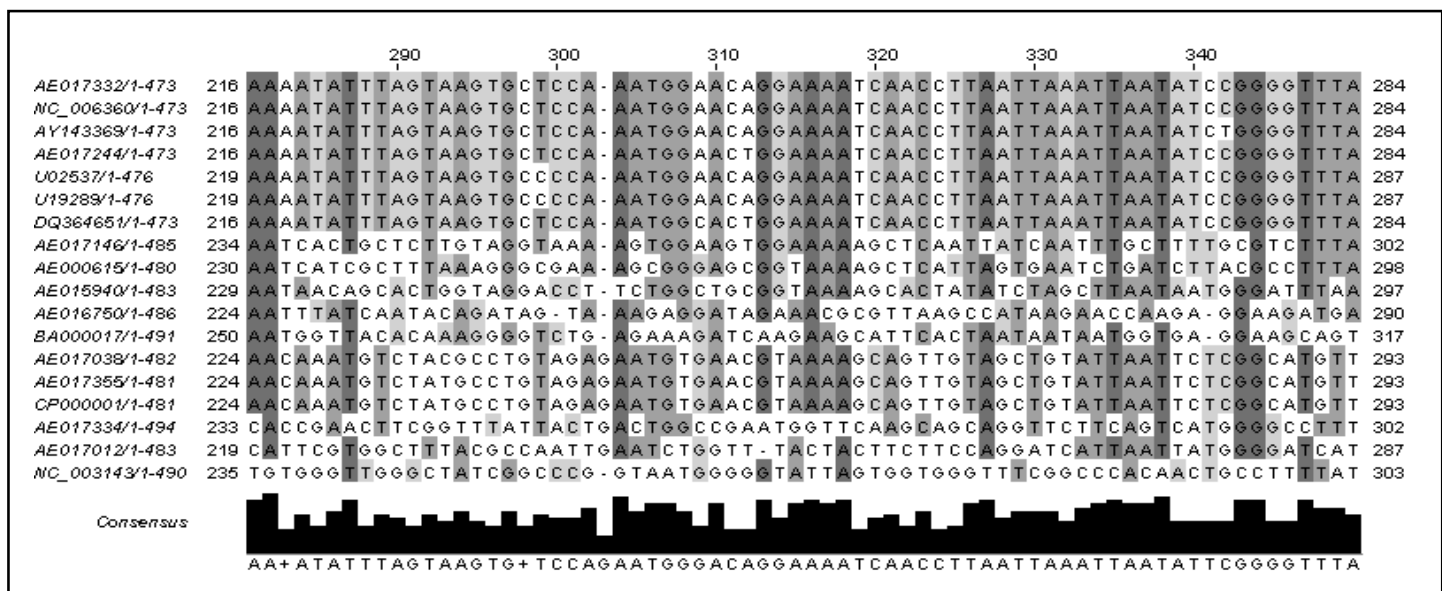

Figure 3. Partial multiple nucleotide alignment of nucleotide sequence of multidrug resistance protein gene, obtained by ClustalW (1.8). The regions with conserved nucleotides are shown in three levels according to the identity. Nucleotide sequence of the isolate of this study is referred to as DQ364651.

${ }^{6}$ Invitrogen - San Diego, USA. 
The usefulness of a nested PCR assay for its fast and sensitive detection of M. hyopneumoniae from lung fragments and nasal swabs has been demonstrated in this report. Once the lung fragment detection is performed on dead animals, nasal swabs are more suitable for $M$. hyopneumoniae detection as it is performed on living animals. Additionally, sample collections are easier, and it could be used to monitor the disease status in pig herds. The isolate fragment found by this work displayed a $99.1 \%$ overall nucleotide homology with $M$. hyopneumoniae sequences retrieved from the GenBank demonstrating that the nested PCR target is highly preserved between $M$. hyopneumoniae which supports the fact that the PCR used in this study would provide an accurate diagnosis.

\section{ACKNOWLEDGMENTS}

We are thankful to Dr. Jalusa Deon Kich from Embrapa Suínos e Aves, who kindly provided the positive control of PCR reactions. We also thank MICROVET for providing the swine tested samples.

\section{REFERENCES}

ALTSCHUL, S.F.; GISH, W.; MILLER, W. et al. Basic local alignment search tool. J. Mol. Biol., v.215, p.403-410, 1990.

AMASS, S.F.; CLARK, L.K.; VAN ALSTINE, W.G. Interaction of Mycoplasma hyopneumoniae and Pasteurella multocida infections in swine. $J$. Am. Vet. Med. Assoc., v.1, p.102-107, 1994.

BLANCHARD, B.; KOBISCH, M.; BOVE, J.M. et al. Polymerase chain reaction for Mycoplasma hyopneumoniae detection in tracheobronchiolar washings from pigs. Mol. Cell. Probes, v.10, p.15-22, 1996a.

BLANCHARD, B.; SAILLARD, C.; KOBISCH, $\mathrm{M}$. et al. Analysis of putative ABC transporter genes in Mycoplasma hyopneumoniae. Microbiology, v.142, p.1855-1862, 1996b.

BUZINHANI, M.; METIFFOGO, E; TIMENETSKY, J. Detecção de Mycoplasma spp. e Ureaplasma diversum em vacas com distúrbios reprodutivos. Arq. Bras. Med. Vet. Zootec., v.59, p.1368-1375, 2007.

CALSAMIGLIA, M.; COLLINS, J.E.; PIJOAN, C. Correlation between the presence of enzootic pneumonia lesions and detection of Mycoplasma hyopneumoniae in bronchial swabs by PCR. Vet. Microbiol., v.76, p.299-303, 2000.

CAlSAMIGLIA, M.; PIJOAN, C.; TRIGO, A. Application of a nested polymerase chain reaction assay to detect Mycoplasma hyopneumoniae from nasal swabs. J. Vet. Diagn. Invest., v.11, p.246-251, 1999.

FREEMAN, M.J.; ARMSTRONG, C.H.; SANDS FREEMAN, L. et al. Serological crossreactivity of porcine reference antisera to Mycoplasma hyopneumoniae, M. flocculare, $M$. hyorhinis and M. hyosynoviae indicated by the enzymelinked immunosorbent assay, complement fixation and indirect hemagglutination tests. Can. J. Comp. Med., v.48, p.202-207, 1984.

HEGE, R.; ZIMMERMANN, W.; SCHEIDEGGER, R. et al. Incidence of reinfections with Mycoplasma hyopneumoniae and Actinobacillus pleuropneumoniae in pig farms located in respiratory disease free regions of Switzerland identification and quantification of risk factors. Acta Vet. Scand., v.43, p.145-156, 2002.

HIGGINS, C.F. ABC transporters: from microorganisms to man. Annu. Rev. Cell. Biol., v.8, p.67-113, 1992.

KURTH, K.T.; HSU, T.; SNOOK, E.R. et al. Use of a Mycoplasma hyopneumoniae nested polymerase chain reaction test to determine the optimal sampling sites in swine. J. Vet. Diagn. Invest., v.14, p.463-469, 2002.

MAES, D.; DELUYKER, H.; VERDONCK, M. et al. Herd factors associated with the seroprevalences of four major respiratory pathogens in slaughter pigs from farrow-to-finish pig herds. Vet. Res., v.31, p.313-327, 2000.

MAROIS, C.; LE CARROU, J.; KOBISCH, M., et al. Isolation of Mycoplasma hyopneumoniae from different sampling sites in experimentally infected and contact SPF piglets. Vet. Microbiol., v.120, p.96-104, 2007.

MAYOR, D.; JORES, J.; KORCZAK, B. M. et al. Multilocus sequence typing (MLST) of Mycoplasma hyopneumoniae: A diverse pathogen with limited clonality. Vet. Microbiol., v.127, p.63-72, 2008. 
MINION, F.C.; LEFKOWITZ, E.J.; MADSEN, M.L. et al. The genome sequence of Mycoplasma hyopneumoniae strain 232, the agent of swine mycoplasmosis. J. Bacteriol., v.186, p.71237133, 2004

OTAGIRI, Y.; ASAI, T.; OKADA, M. et al. Detection of Mycoplasma hyopneumoniae in lung and nasal swabs from pigs by nested PCR and culture methods. J. Vet. Med. Sci., v.67, p.801-805, 2005.

RIBEIRO, F.C.; SILVA, J.C.P.; SANTOS, J.L. et al. Diagnóstico da pneumonia enzoótica suína pela técnica da imunoperoxidase. Arq. Bras. Med. Vet. Zootec., v.56, p.709-714, 2004.

ROSS, R.F. Mycoplasmal diseases. In: LEMAN, A.D.; STRAW, B.E.; MENGELING, W.L. et al. (Eds). Diseases of swine. 7.ed. Ames: Iowa State University, 1992. p.537-551.

ROSS, R.F. Mycoplasmal diseases. In: STRAW, B.E.; D'ALLAIRE, S.; MENGELING, W.L. et al. (Eds). Eight diseases of swine. Ames: Iowa State University, 1999. p.495-510.

SAMBROOK, J.; FRITSCH, E.F.; MANIATIS, T. Molecular cloning: a laboratory manual. 2.ed. New York: Cold Spring Harbor Laboratory Press, 1989. 608p.

SOBESTIANSKY, J.P.; MATOS, M.P.C.; HIROSE, F. Pneumonia enzoótica suína: prevalência, impacto econômico, fatores de risco e estratégias de controle. Goiânia: Art 3 Impressos Especiais, 2001. 43p.

SORENSEN, V.; AHRENS, P.; BARFOD, K. et al. Mycoplasma hyopneumoniae infection in pigs: duration of the disease and evaluation of four diagnostic assays. Vet. Microbiol., v.54, p.23-34, 1997.
STARK, K.; NICOLET, J.; FREY, J. Detection of Mycoplasma hyopneumoniae by air sampling with a nested PCR assay. Appl. Environ. Microbiol., v.64, p.543-548, 1998.

STRASSER, M.; ABIVEN, P.; KOBISCH, M. et al. Immunological and pathological reactions in piglets experimentally infected with Mycoplasma hyopneumoniae and/or Mycoplasma flocculare. Vet. Immunol. Immunopathol., v.31, p.141-153, 1992.

THACKER, E.L. Mycoplasmal disease. In: STRAW, B.E., ZIMMERMANN, J.J., D'ALLAIRE, S. et al. (Eds.). Diseases of swine. 9.ed. Ames: Iowa State University, 2006. p.701717.

THOMPSON, J.D.; HIGGINS, D.G.; GIBSON, T.J. et al. improving the sensitivity of progressive multiple sequence alignment through sequence weighting, positions-specific gap penalties and weight matrix choice. Nucleic Acids Res., v.22, p.4673-4680, 1994.

VERDIN, E.; SAILLARD, C.; LABBE, A. et al. A nested PCR assay for the detection of Mycoplasma hyopneumoniae in tracheobronchiolar washings from pigs. Vet. Microbiol., v.76, p.31-40, 2000.

WHITFORD, H.W.; ROSENBUSCH, R.F.; LAUERMAN, L.H. (Eds). Mycoplasmosis in animals: laboratory diagnosis. Ames: Iowa State University, 1994. 173p.

YAGIHASHI, T.; NUNOYA, T.; MITUI, T. Effect of Mycoplasma hyopneumoniae infection on the development of Haemophilus pleuropneumoniae pneumonia in pigs. Nip. Juig. Zas., v.46, p.705-713, 1984. 